\title{
Public engagement and climate adaptation: insights from three local governments in Australia
}

\begin{abstract}
Public participation in decision-making is a central component of the planning process; however, implementing effective engagement initiatives to resolve complex planning and policy problems, such as climate change, is challenging for planners. These challenges are particularly acute in coastal communities throughout Australia where many settlements are at risk of future climate perturbations. Using the International Association for Public Participation (IAP2) framework for public participation, we analyse three local government-led public participation initiatives in New South Wales, Victoria and Tasmania, Australia. Our analysis suggests there are three critical factors that can influence the level of public participation in the context of climate change adaptation: the technocratic approach to decision-making; absent high-order government support; and the lack of evaluation mechanisms for public participation.
\end{abstract}

Key words: consultation, planning, participation, decision-making, coastal hazards 


\section{Introduction}

Since the 1990s, there has been growing recognition of the need for greater public participation in decision-making processes in many areas under the responsibility of the public governance domain, including land use planning (Healey 1992; Giddens 1998; Connelly and Richardson 2004). In this paper, public participation refers to 'episodic' relationships between civil society and government authorities as opposed to public engagement where relationships are 'ongoing and active' (Head 2007).

In the planning sector, Healey $(1992,2006)$ suggested that the use of collaborative approaches could significantly improve public participation, promote collective debate and increase legitimacy of decisions. However, collaborative approaches to decision-making involving the planning sector have been subject to criticism and debate amongst scholars. While Healey (2006) claimed that critics heavily focused on issues related to consensus-building, other concerns indicated that greater public involvement in decision-making did not ensure highquality planning outcomes (Brody 2003). Additionally, McGuirk (2001) stated that collaborative approaches are problematic because both planning practice and decisions are politically charged and influenced by an uneven distribution of power between involved actors.

While public participation is mandated for land use planning decisions in most Australian state jurisdictions, the eminent threat of climate change impacts brings an additional element that needs to be considered by the planning sector. For instance, Australia's highly urbanised coastal areas have been identified as being 
vulnerable to climate-induced coastal hazards, including coastal erosion and inundation (CSIRO 2007; Hennessy et al. 2007; Norman 2010). Given that projected climate change impacts will be mostly experienced at the local scale, an effective response will inevitably require the involvement of local actors in the decision-making process (Hobson and Niemeyer 2011; Burton and Mustelin 2013). In particular, engaging the public in deliberation regarding adaptation initiatives can greatly improve their understanding of climate change, including future projections, impacts and responses (Wiseman, Williamson, and Fritze 2010; Hobson and Niemeyer 2011). Additionally, complex problems such as climate change that demand costly and controversial solutions may in fact benefit from bringing together diverse stakeholders as this may assist in reducing conflict and problem-solving (Hemmati 2002 and Curtain 2006 cited in Head 2011).

Despite the many favourable arguments towards public participation in decisionmaking processes, scholars claim that it remains a challenging task for decisionmakers and practitioners (Fischer 2006; Renn 2006; Conrad et al. 2011). For example, Adger (2003) identified the potential for equity issues to emerge when decisions and risk management options exclude input from key vulnerable groups. Lorenzoni, Nicholson-Cole, and Whitmarsh (2007) noted the limitations of public participation initiatives that focus on providing scientifically sound information but ignore the potential subjectivism involved in interpreting climate science. The authors also identified a series of barriers at the individual and social scales that prevent the public from engaging with climate change issues. 
These include, but are not limited to, 'uncertainty and scepticism', 'distrust in information sources' and 'lack of political action'.

Other authors suggested that low levels of support from high-order governments undermines public participation efforts involving the discussion and implementation of contentious policies such as planned retreat (Gurran et al. 2011; Low Choy et al. 2012; Harman et al. 2013). This is also evident in policy debates that consider cost-sharing arrangements associated with adaptation options, particularly where the benefits are not expected to be evenly distributed throughout society (Camacho 2009).

To this end, the paper aims to discuss key challenges and distil insights that can inform future public participation for climate change adaptation involving land use planning initiatives. Applying the International Association for Public Participation (IAP2 2007) framework, three local government-led public participation initiatives involving climate change issues are analysed: (1) Gosford City Council, New South Wales (NSW); (2) Wellington Shire Council, Victoria (VIC); and (3) Clarence City Council, Tasmania (TAS).

\section{Research approach}

As local authorities are at the forefront of climate change impacts (Measham et al. 2011), it is critical to improve our understanding of the challenges they face when undertaking public participation associated with climate change adaptation in land use planning. Given the climate change vulnerability of Australia's urbanised coastal areas, a preliminary document search was carried out to identify coastal local authorities addressing climate change vulnerabilities in the 
states of NSW, VIC and TAS. Different state jurisdictions were selected to enable a comparative assessment of the extent to which different institutional arrangements influence how local authorities engage in public participation initiatives related to climate change adaptation. At the time of writing, these three states had official initiatives set at the state level that encouraged climate change adaptation to take place at the local level, namely: a state planning policy for sea level rise in NSW ${ }^{1}$ (NSW Sea Level Rise Policy Statement 2009); the Future Coasts Program in VIC (State Government of Victoria undated); and the Coastal Adaptation Decision Pathways Project in TAS (Department of Premier and Cabinet 2011). The following key criteria were applied to guide the selection of case studies in each state jurisdiction:

(i) Recognised exposure of community and public assets to future climate change risk associated with coastal hazards based on the First Pass National Assessment (Department of Climate Change 2009);

(ii) Existing public participation initiative related to climate change adaptation involving planning processes; and

(iii) Level of complexity and urgency of challenges faced by land use planning processes (e.g. erodible shorelines demanding immediate action).

The preliminary search comprised online documents available through local governments' websites, including planning policies, plans and strategies; climate change impact studies; media releases; and secondary reports analysing climate change adaptation initiatives. Following this initial screening, three local 
government case study areas were identified (see Figure 1). The authors acknowledge that selected case studies are purely illustrative rather than representative of what is occurring across Australia more broadly. A comparative analysis involving local authorities across all Australian states could be the subject of future studies, particularly in light of ongoing planning reforms.

\section{[Insert Figure 1 near here]}

An in-depth documentary analysis was subsequently undertaken to investigate the challenges these local authorities were facing when involving the public to address climate change related issues. This included a review of all relevant state, regional and local plans and policies directly associated with planning; climate change adaptation and public engagement strategies; official media releases disseminated by both state and local governments; and local newspaper and media articles.

One semi-structured phone interview per case study area was conducted in JulyAugust 2012 to verify the information obtained through the documentary analysis. Interviews lasted approximately 30-40min and comprised senior practitioners who were engaged in land use and adaptation planning and public engagement initiatives. The interview questions focused on the following key areas: (i) confirmation of the current approach to public engagement adopted by the local authority; (ii) confirmation of the level of public participation related to planning for climate change impacts; (iii) perceived effectiveness of different engagement strategies and tools; (iv) perceived barriers and opportunities to engaging the public on climate change related matters; and (v) the relative influence of state 
legislation on the level of public participation undertaken by local authorities involving planning initiatives targeting climate change adaptation. These questions guided the coding and content analysis of interviews. Thus a deductive approach was employed to coding and analysing the data. Information obtained through interviews is referred to in the text as follows: GCC for Gosford City Council; WSC for Wellington Shire Council; and CCC for Clarence City Council.

Given that the three local authorities adopt the IAP2 framework in their community engagement plans (Gosford City Council undated; Wellington Shire Council 2011; Clarence City Council 2010), the analysis predominantly focuses on planning processes (see Table 1). For Gosford City, the analysis concentrates on formal planning processes related to sea level rise across the whole local government area. For Wellington Shire, the focus is on formal planning processes for coastal hazards and environmental issues concerning the Ninety Mile Beach area. Finally, the Clarence City analysis focuses on a local project aimed at improving understanding of risks, community expectations and management related to climate change.

[Insert Table 1 near here]

\subsection{Forms and methods for public participation in decision-making}

Evolving forms and methods used to guide public participation initiatives in Australia and elsewhere have been largely based on Arnstein's participatory ladder (Head 2011). Arnstein's ladder comprises eight levels of participation where each level corresponds to the extent of power citizens have in 'determining the end product' (cf. Arnstein 1969). Based on this ladder, public 
participation initiatives can be ranked from non-participation through to degrees of tokenism and degrees of citizen power.

Collaborative approaches to decision-making processes defended by Healey (1992, 2006) would be positioned in the upper levels of the ladder as these involve partnership, delegated power and citizen control levels. However, Head (2011) noted that the ladder approach assumes a progressive level of public participation in decision-making considered to be unachievable in situations where governments cannot share, nor delegate, power and control with their citizens. As a result, governments and community groups in many modern democracies have sought alternative approaches to guide and evaluate public participation processes such as the IAP2 framework (Head 2011).

While the IAP2 framework also includes participatory levels conducive to collaborative approaches to decision-making, it has a 'more contextual and situational' approach rather than the progressive approach to public participation conveyed by Arnstein's ladder (cf. Head 2011). Developed from practitioner's experiences, the IAP2 framework comprises five levels of increasing public participation with different goals and tools for each level: information, consultation, involvement, collaboration and empowerment (see Figure 2).

[Insert Figure 2 near here]

The IAP2 framework is useful to extract insights about how deliberation in public participation associated with climate change adaptation initiatives is constrained or enabled based on both participation methods and the targeted problem. 


\section{Applying the IAP2 framework}

Following a brief description of the three cases, the IAP2 framework is applied to extract key insights related to public participation in the context of climate change adaptation.

Case 1: Gosford City Council - implementing a new state policy

The Gosford City Council area is identified as the third most vulnerable area to sea level rise in NSW (Department of Climate Change 2009). The Council began to formally plan for sea level rise impacts in 2009 when it adopted the NSW State Sea Level Rise planning benchmarks (Gosford City Council 2010). This planning process involved consultation with existing committees as well as task and reference groups that included key community representatives in their membership (GCC). Council prepared a series of instruments to communicate with the public, including fact sheets, letters to property owners, media releases and two sets of maps that provided an initial indication of areas vulnerable to extreme sea levels (GCC). These maps were publicly exhibited and made available through the Council's website. In response to the display of maps, Council received a small number (16) of public submissions with mixed feedback showing both support for and opposition to the initiative (GCC).

Greater public interest, in turn, occurred when Council started to include an advisory notification on planning certificates s149(5) based on these hazard maps to inform property owners of the risk of a sea level rise of up to $90 \mathrm{~cm}$ by 2100. A greater public response (around 200) was received compared to the previous exhibition. In particular, the public sought clarification about the 
notification and questioned anthropogenic-led sea level rise (GCC). It was evident that residents became more concerned when the issues became more formalised through notification on planning certificates; thus potentially impacting property values.

Key findings

In terms of the public participation levels set by the IAP2 framework, this local authority concentrated on generating detailed information for the public, largely accomplishing the Information and Consultation levels (see Table 2).

[Insert Table 2 near here]

Nevertheless, while the information related to existing and future risks was quite comprehensive and detailed; the interpretation of the temporal elements of such information by the public was problematic, requiring a rethink on how to best communicate existing and future risks:

...we really need to separate the way we communicate existing flood risk from future flood risk and we are indeed to move forward, we are going to simplify the mapping so we don't have a whole series of maps. (GCC)

Similar to other local authorities in NSW, the Collaboration level in public participation initiatives exhibited by this case was predominantly represented by their engagement with a variety of advisory and consultative bodies that have representatives from the community. These included a coastal and estuary management committee, a floodplain risk management committee and a task group for the Cities for Climate Protection program (GCC). 
This form of Collaboration can provide scope for deliberation upon critical issues as well as transparency in decision-making. Additionally, it offers potential to build community capacity (Quick and Feldman 2011) and social capital by establishing new networks (Olsson 2009). While citizens may be more motivated to participate when their interests are better captured in the final decisions (Hopkins 2008; Yetano et al. 2010), many may also participate because of 'relational rewards', including network membership, network position and information and knowledge spillovers (cf. Olsson 2009). On the other hand, citizens may choose not to participate, therefore questioning the extent of community representation in these specialised committees and consultative bodies (Head 2007).

Evidence for pursuing the Involvement level was absent in this Council initiative. In fact, although Council had participated in fora organised by community groups, the inclusion of the advisory notification on planning certificates triggered a community-led pressure for Involvement. Organised community groups kept close attention to planning decisions sought by Council:

Basically we got a considerable amount of community response, and to the point over the last few years the community now has formed groups that are even going to the point of having rallies in the street outside council, coming to all council meeting to anything relating to our strategic planning processes, someone will speak publically in these organised effort, they are influencing the media... (GCC)

While mandated public participation in most Australian states ensures some form of consultation occurs, participation becomes problematic when the public is involved at a late stage of the planning process (Lahiri-Dutt 2004). Consequently, 
planning decisions may end up being challenged rather than supported by the community. From a practitioner's perspective, this public reaction also occurred due to the lack of high-order government support:

I certainly think the state government could better support local government and roll out some kind of education strategy ... to do that. There was no support. We were in it alone really and pretty much got hammered as guinea pigs for that process. (GCC)

While the Empowerment level was also not directly pursued by the other cases as described later, there appears to be a clear message emerging from this case that Empowerment is only possible when the public detains sufficient expertise in the field:

We would be working with the community to come up with the most suitable and appropriate option for any individual foreshore location but they don't have all the information, council engages technical experts external to the organisation to undertake those rigorous studies and that's where we need to form our basis. (GCC)

One of the barriers to effective public participation still rests with the reluctance of governments to devolve power and control of decisions to the public (Head 2007). This case reinforces the trend identified in climate change adaptation initiatives in Australia where the public is often seen as an important partner in the implementation of policies but not necessarily in their development phase (see Burton and Mustelin 2013). However, given that climate science uncertainty continues to be a key barrier to land use planning for climate change adaptation at the local scale (Milly et al. 2008; Quay 2010), 'adaptation strategy must seek legitimacy through a certain level of social acceptance among the public' (Burton and Mustelin 2013: 13). Additionally, deliberation is critical to defining the role 
and relevance of scientific information and locally based knowledge when decisions can affect large populations (Renn 2006).

Case 2: Wellington Shire Council - dealing with the legacy of past planning decisions

Wellington Shire is particularly vulnerable to flooding and coastal inundation (Department of Planning and Community Development 2007). Of particular concern is the Ninety Mile Beach area which has been identified as one of the most vulnerable coastal areas in Australia (Department of Climate Change 2009). Ninety Mile Beach is a $25 \mathrm{~km}$ strip of ocean foreshore where housing estates such as The Honeysuckles have been 'inappropriately' developed in the 1950 and 1960s given the area's significant environmental value (cf. Wellington Shire Council 2007:10). To address this issue, an Urban Design Framework (UDF) was developed by Wellington Shire Council in collaboration with community advisory groups and networks (Butler 2005). The UDF aimed to guide future developments along this vulnerable and environmentally sensitive area in terms of their 'location, type and extent' (Meinhardt Infrastructure \& Environment Pty Ltd 2007: 2).

To implement the UDF, Council proceeded to amend its planning scheme which involved consultation and hearings conducted by an independent panel that confirmed the sensitivity related to dealing with property rights (Wimbush, Holdsworth, and Gowans 2009). Previously, the release of a climate change study on impacts upon the Ninety Mile Beach area (ETHOS NRM Pty Ltd and Water Technology 2008), followed by a moratorium on further development 
imposed by statutory planning controls (Wimbush, Holdsworth, and Gowans 2009), triggered a strong reaction from the public predominately associated with a decrease in property values (Braithwaite 2008; Golden Beach Property Rights Action Group 2008; WSC).

Despite community concerns, planning controls to curb further development are currently in place for selected areas along Ninety Mile Beach along with a Voluntary Assistance Scheme which includes transfer of vacant land to Council and payments to land owners (Wellington Shire Council 2012). It is important to note, however, that current planning controls are based on the area's significant environmental values and identified rural conservation zones (Wellington Shire Council undated) rather than future climate change risks despite the identification of those risks in the UDF (Meinhardt Infrastructure \& Environment Pty Ltd 2007).

Key findings

Similar to case 1, the Information and Consultation levels of the IAP2 framework were largely accomplished by Wellington Shire. As listed in Table 2, a range of methods were used to communicate with the public, particularly when the UDF was developed. However, public participation initiatives involving planning decisions predominantly follow what is required by legislation:

The Council does have a communication strategy but we usually don't really use it. Most of the consultation we do with the community follows the requirements existing in the current legislation. (WSC)

This is illustrative of a top-down and tokenistic approach to public participation in the planning sector which can contribute to diminishing public trust and hinder 
the achievement of stronger forms of participation such as Involvement, Collaboration and Empowerment (Eshuis and Van Woerkum 2003; Connelly and Richardson 2004; Hartz-Karp 2004; Brownill 2007; Conrad et al. 2011).

In terms of the Collaboration level, similarly to Gosford City, community advisory groups and networks were able to provide feedback and advice to proposed strategies such as the UDF. Interestingly, consultants conducted this part of the public participation exercise. Consultants are also often engaged to provide additional expertise when larger or complex projects are at stake:

It is advantageous to engage consultants when there is lack of expertise within council staff as this gives extra credit when dealing with the community, particularly on technical issues. (WSC)

Taylor, Harman, and Inman (2013) noted that external expertise has been frequently used by government agencies to deal with the increasing technical complexity involved in mapping and assessing climate change risks, particularly coastal hazards. The lack of internal capacity and a rapidly changing policy environment is also used to justify the use of external expertise to aid and support decision-making (Steele 2009; Taylor, Harman, and Inman 2013). In relying on the work provided by consultants, local governments may be limiting their opportunity for building institutional capacity to deal with complex issues such as climate change. Additionally, consultants may become the key channel of communication between governments and communities, thereby reducing the opportunity for developing better council-community relationships.

Techniques favouring the Involvement level of the IAP2 frameworks were also absent. While top-down and tokenistic approaches to participation can lead to 
increased public 'apathy' and 'consultation fatigue' (cf. Connelly and Richardson 2004: 11-12), it may also trigger conflicts between the parties involved. In this case, conflicts between property owners and local and state government agencies have intensified over the last decade due to more stringent planning decisions and controls aimed at curbing future development in the area:

As a group we are objecting to all issues that affect our property rights, the value of our land, and the lack of services for the rates charged. (Ninety Mile Beach Property Rights Group)

Australian urban areas have a legacy of past planning decisions such as this one illustrated by the Ninety Mile Beach that place many private and public assets as well as communities at an increased risk of harm from climate change impacts (McDonald et al. 2010). While this case provides an illustration of the type of disputes over compensation claims that are likely to be faced by local and state governments as the risk of impacts intensifies (McDonald 2010), it also indicates that there is a greater need for effective public participation to legitimise planning decisions and seek socially acceptable solutions.

In terms of the Empowerment level proposed by the IAP2 framework, the Wellington Shire Council's community engagement strategy (Wellington Shire Council 2011) clearly states that this level is unachievable due to current regulatory arrangements. Specifically, Council states that Empowerment conflicts with the Local Government Act 1989 (VIC) which ultimately conveys the responsibility of decisions to elected members. On the one hand, by clearly communicating which goals its public engagement initiatives are able to achieve, Council avoids shortcomings of often claimed 'bottom-up' approaches and does 
not raise false expectations (Few, Brown, and Tompkins 2007). On the other hand, Council could be deflecting the need for stronger forms of participation and confirm the reluctance of governments to devolve power and control of decisions to the public (Head 2007).

\section{Case 3: Clarence City Council - responding to urgent threats}

The Clarence region has had a history of coastal erosion and inundation which triggered a number of previous investigations and technical assessments (Water Research Laboratory (WRL) 2011; Aquenal Pty Ltd 2010a, 2010b). These studies found that the rate of beach recession in some locations had accelerated in the past decade, raising concerns regarding the cost and effectiveness of various planning and management responses (The Mercury 2012). This has been particularly problematic around Lauderdale where residential dwellings are already susceptible to coastal inundation due to storm surge activity (CCC).

To address this issue Council implemented a project entitled: Climate Change Impacts on Clarence Coastal Areas (Clarence City Council 2009). The project aimed to explore and identify adaptation options as well as provide opportunities for community consultation and dissemination of information (Clarence City Council 2009). As part of the project, two public fora were held in the two most affected areas of Clarence City (Lauderdale and South Arm). Approximately 300 people attended these fora in which detailed findings of the project and a summary of proposed policy options were discussed with the public. The high attendance at the public fora, along with extensive mail outs and press coverage, indicated a high awareness of the project in the affected areas (Clarence City 
Council 2009). The high attendance rate was also attributed to the fact that Council held the event shortly after extreme weather events affected the area (CCC).

Additionally, Council capitalised on an existing project established by the state government - the Tasmanian Coastal Adaptation Decision Pathways (TCAP) (Department of Premier and Cabinet 2011) - to develop long term responses to climate change in Lauderdale (CCC). This project encompassed previous studies and investigations and input from community members, which involved approximately 125 people, including residents considered to be in 'at risk' areas, and observers from state and local governments. An information session was held to update the local community on the progress of risk and hazard studies and to introduce adaptation pathways to be investigated at two subsequent workshops (SGS Economics and Planning 2012). Workshops aimed to investigate adaptation pathways and to develop "community driven solutions" (CCC).

Key findings

Similar to the other case studies, the Information and Consultation levels of the IAP2 framework were also accomplished by Clarence City. In addition to printed material such as technical reports available through their website, Council also hosted community surveys and information sessions for the public in two localities that were facing significant coastal erosion (see Table 2). In particular, these sessions were delivered by a 'cooperative of four agencies' including the 
Council itself, consultants and scientists from two research centres (CCC). Many people in the community accept the science (CCC), however:

There is a significant amount of stress associated with it because it not only threatens their property but it threatens their property values so it makes it hard for them to extricate themselves from that situation. (CCC)

The issue associated with property values was also raised by the other two cases and it brings to the spotlight the need for further discussion with affected stakeholders about the alternatives that lay at hand. As climate change adaptation responses may be costly, there is a need to debate which segments of the community should bear the economic burden of adaption solutions (Camacho 2009).

By contrast, out of the three cases, Clarence was the only one that used engagement techniques that contributed to achieving the Involvement level of the IAP2 framework, particularly to discuss alternative solutions to coastal erosion problems. The importance of using a range of participative techniques such as small group discussions and ranking exercises in workshops to encourage active participation and deliberation is well recognised (Videira et al. 2006; Few, Brown, and Tompkins 2007; Hindmarsh and Matthews 2008). Indeed, deliberation encourages two-way information and knowledge exchange between stakeholder groups, enabling policy decisions to be informed by affected parties (Videira et al. 2006). Additionally, affected residents are given the opportunity to collaborate in the decision-making process: 
Basically we just spent a number of hours just sitting round a table trying to come up with solutions that the community felt was - trying to come up with community-driven solutions. (CCC)

Council is further investigating options related to the preferred pathway identified by the participants at the workshops, which was to "protect existing development as long as practical while protecting property values in preference to natural processes" (CCC). However, although this initiative encouraged a deliberative approach with the community, Collaboration and Involvement only took place after 'experts' devised the alternative solutions.

In terms of the Empowerment level of the IAP2 framework, Council maintains that empowerment could still be achieved in two possible ways: (i) through Council adopting recommendations from the community; and/or (ii) by authorising an entity within the community to proceed with a task that involves a degree of decision-making (Clarence City Council 2010). At the time of writing this has not been exercised or achieved.

\section{Key insights for public participation for climate change adaptation}

Findings emerging from the case studies suggest that there are three critical factors that can influence the level of public participation in the context of climate change adaptation: the technocratic approach to decision-making; absent highorder government support; and the lack of evaluation mechanisms for public participation.

The technocratic approach to decision-making 
The case studies revealed that there is a trend towards seeking technocratic solutions to justify land use planning decisions with a focus on climate change adaptation. Despite the limitations of available climate change science in guiding land use planning (Milly et al. 2008; Quay 2010), the technocratic approach appears to reinforce the idea that reaching the Information and Consultation levels in public participation are sufficient to deal with climate change risks.

Information alone, albeit detailed and comprehensive, may not be sufficient to achieve successful and, more importantly, socially acceptable solutions even when those solutions have a statutory character. Hence, the participation of the public in more than one stage of the policy cycle needs to be improved (Burton and Mustelin 2013). This is supported by the fact that the highly technical and dynamic nature of climate change requires better relationships and improved trust between governments and the public (Jamieson 2006; Few, Brown, and Tompkins 2007; Leitch, Harman, and Lane 2010). While in some situations adaptation planning may be better suited to expert-led discussion, the inclusion of the public can provide the necessary check on the value judgement of experts given that public participation initiatives 'ought to be a democratic process' (Renn 2006:40).

Additionally, plausible alternative solutions to potential climate change risks need to be sourced, developed and discussed with the public along with clear articulation of expected outcomes (Kloprogge and Sluijs 2006). For example, the disclosure of risks may have a direct impact upon property rights and values as 
identified by the case studies; hence it is critical to involve affected parties to discuss proposed solutions (Mercer and Jotkowitz 2000).

Last, the availability of scientific / technical information related to climate change science does not ensure that planning decisions will be made based on the evidence they provided (Serrao-Neumann, Harman, and Low Choy 2013). In fact, in the Australian context, land use planning decisions have been politically focused and often driven by private sector and economic interests (Measham et al. 2011; Taylor, Harman, and Inman 2013). The challenge thus lies with defining best strategies that ensure these decisions also incorporate the best available science in association with best alternative solutions for affected communities. Involving the community beyond the Information and Consultation levels and throughout the entire planning process is critical to the success of such strategies.

Absent high-order government support for climate change adaptation

Public participation in the Australian planning sector is a legislative requirement set by state governments (Head 2011). Given that subsidiarity applies, local governments usually lead the public participation process (e.g. VIC Planning and Environment Act 1987; NSW Environmental Planning and Assessment Regulation 2000; TAS Land Use Planning and Approvals Act 1993). However, as illustrated by the case studies, the mandated character of participation does not necessarily translate to stronger forms of public participation. In fact, often statutory participation results in top-down (Keen, Mercer, and Woodfull 1994; Lahiri-Dutt 2004; Brackertz and Meredyth 2009; Manwaring 2010) and tokenistic 
approaches (Mercer and Jotkowitz 2000; Osborne, Bacchi, and Mackenzie 2008; Manwaring 2010) that are mostly representative of the 'placation' stage of Arnstein's participation ladder (Hindmarsh and Matthews 2008). This top-down and tokenistic character of public participation is further compounded when Empowerment is also impeded by current legislation (for example, the Local Government Act 1989 [VIC]).

Given that the effects of climate change will be mostly felt at the local scale, adaptation is profoundly considered a local problem requiring a local response (Agrawal 2008; Measham et al. 2011). However, adaptation planning is also widely recognised as being multi-dimensional and thus requiring a diversity of responses that cut across all sectors and scales of governance (Harman et al. 2013; Serrao-Neumann et al. 2013). Hence, the absence of high-order government support to implement statutory policies at the local level adds extra pressure on the already stretched capacity of local authorities to deal with the implications of those policies for their communities. It also complicates the implementation of public participation initiatives seeking stronger forms of public participation (i.e. Involvement, Collaboration and Empowerment), particularly when they involve contentious and costly policies.

Interestingly, interviewees saw this situation as an opportunity to trigger a 'wholeof-the-government approach' in which councils, state and federal governments work together to improve public participation and education and establish sound legislation and management options to deal with future climate change impacts. The need for improved leadership, better coordination and real engagement 
across industry, government and the community has also emerged in more recent climate change adaptation studies involving local government stakeholders across Australia (Gurran et al. 2011; Low Choy et al. 2012).

\section{Lack of evaluation mechanisms for public participation}

Despite the mandated character to public participation in land use planning decisions, there is no indication as to how best to evaluate these initiatives, nor are there structures that facilitate such evaluation. There are also difficulties related to how best to engage the public effectively and representatively (Few, Brown, and Tompkins 2007). For example, the case studies indicated that the stage and timing at which the public is involved in the planning process might lead to public support for (pre-regulation phase in the Clarence case), or opposition to decisions (regulation phase in the Gosford and Wellington cases). As highlighted by Burton and Mustelin (2013), when governments assume that the public is willing to engage in policy development processes without greater public awareness of the problem being targeted governments might experience community resistance rather than support.

Sutton and Tobin (2011) also found that the individual's lack of knowledge about the process or problem being targeted comprised a constraint to engagement. Additionally, public scepticism and uncertainty related to human induced climate change can also hamper public support for climate change adaptation policies (Poortinga et al. 2011). Strategies to overcome these challenges could include comprehensive communication plans to better target different stakeholder groups and tailor more salient information to stakeholders (Clarence City Council 2009). 
Indeed, identifying the appropriate stakeholders and being sensitive to inequalities of social power is also important in the design of community engagement strategies (Few, Brown, and Tompkins 2007).

As observed in the case studies, many governments have turned to advisory/consultative committees that include key representatives from their communities as a form of public participation in decision-making. However, it is difficult to measure the degree of representativeness of these individuals on behalf of their communities. It is also difficult to gauge the extent to which the Involvement and Collaboration levels are accomplished by this form of engagement.

Burton and Mustelin (2013) stated that greater public participation does not necessarily translate into better outcomes but they convey greater legitimacy to decisions. However, evaluating public participation is not only necessary in terms of the quantity and level of representativeness achieved but also whether they indeed facilitate stronger forms of public participation, particularly Involvement, Collaboration and Empowerment. A number of strategies have been identified to be conducive to promote stronger levels of public participation. These include participatory (Toth and Hizsnyik 2008), deliberative (Videira et al. 2006; Hindmarsh and Matthews 2008) and co-operative (Renn 2006) techniques that support future decisions on desired adaptation pathways.

Nevertheless, how can the efficiency of these deliberation exercises be evaluated to define whether they were conducive to achieving stronger levels of public participation as well as pathways that are technically sound and socially 
acceptable? Moser (2009) suggests that it is important that decision support goals and desirable outcomes need to be clearly defined to provide sufficient information for a sound assessment. These include substantive goals to enhance the understanding of the process and needed information; normative goals to ensure the process is democratic; and instrumental goals to secure greater public legitimacy to decisions. However, baseline data is needed to benchmark the impact of the process (Moser 2009), therefore sufficient resources (financial and human capacity) need to be allocated to ensure both the public participation initiative and its evaluation process are successfully accomplished.

This paper analysed three Australian local government-led public participation initiatives for climate change adaptation by applying the IAP2 framework. The findings highlight three critical factors that need to be considered to achieve stronger levels of public participation for climate change adaptation: the technocratic approach to decision-making; absent high-order government support; and the lack of evaluation mechanisms for public participation. Improving the quality of information will help to address local government's liability concerns and support effective decision-making, particularly in terms of identifying best management options (NCCARF et al. 2012). However, public participation initiatives need to go beyond the provision of sound technical / scientific information and include deliberation about climate change impacts to also determine shared responsibilities between the public and private sectors and communities to address potential problems caused by those impacts. Indeed, creating a forum for proactive deliberation that allows citizens to engage early 
and meaningfully in the process is critically important in the context of climate change adaptation as it provides stakeholders with a 'genuine opportunity to construct, discuss and promote alternative options' (Few, Brown, and Tompkins 2007: 56). Furthermore, the achievement of stronger forms of public participation in light of climate change requires sound political leadership that supports the implementation of such initiatives at the local level, particularly when planning decisions are set to have trade-offs for individuals and the community. Last, stronger forms of public participation can only be assessed upon the existence of both better evaluation mechanisms and baseline data. Perhaps this should be the starting point for any mandated public participation process. 


\section{Notes}

${ }^{1}$ Since the research was conducted, the NSW Sea-Level Rise Policy, including planning benchmarks and notations on planning certificates, has been revoked by the NSW State Government.

\section{Acknowledgement}

The authors would like to thank the reviewers for their constructive comments.

\section{References}

Adger, W. 2003. "Social aspects of adaptive capacity " In Climate change, adaptive capacity and development, edited by R. Klein \& S. Huq eds. J. Smith, 29-50. London: Imperial College Press.

Agrawal, A. 2008. The role of local institutions in adaptation to climate change. Papers of the Social Dimensions of Climate Change Workshop. Washington DC: The World Bank, March 5-6.

Aquenal Pty Ltd. 2010a. Beach sand profile at Roches Beach, Tasmania.

—. 2010b. Roches and Cremorne Beaches - Habitat Mapping, Bathymetry and Sediment Analysis.

Arnstein, S. R. 1969. "A Ladder Of Citizen Participation." Journal of the American Institute of Planners no. 35 (4):216-224. doi: 10.1080/01944366908977225.

Brackertz, N., and D. Meredyth. 2009. "Community Consultation in Victorian Local Government: A Case of Mixing Metaphors?" Australian Journal of Public Administration no. 68 (2):152-166. doi: 10.1111/j.14678500.2009.00627.x.

Braithwaite, D. Climate change doubt 2008. Available from http://sale.yourguide.com.au/news/local/news/general/climate-change douu....

Brody, S. D. 2003. "Measuring the Effects of Stakeholder Participation on the Quality of Local Plans Based on the Principles of Collaborative Ecosystem Management." Journal of Planning Education and Research no. 22 (4):407-419. doi: 10.1177/0739456x03022004007.

Brownill, S., and J. Carpenter. 2007. "Increasing participation in planning: Emergent experiences of the reformed planning system in England." Planning Practice and Research no. 22 (4):619-634.

Burton, P., and J. Mustelin. 2013. "Planning for Climate Change: Is Greater Public Participation the Key to Success?" Urban Policy and Research:117. doi: $10.1080 / 08111146.2013 .778196$. 
Butler, G. 2005. Sustainable communities: the important role of local government in building social capital. In 2nd Future of Australia's Country Towns Conference. Bendigo.

Camacho, A. 2009. "Adapting governance to climate change: managing uncertainty." Emory Law Journal no. 59 (1):1-70.

Clarence City Council. 2009. Climate change impacts in Clarence coastal areas. Clarence City Council.

—. 2010. Clarence Community Participation Policy 2010. Clarence City Council.

- 2012. A future for Lauderdale. Clarence City Council.

Connelly, S., and T. Richardson. 2004. "Exclusion: the necessary difference between ideal and practical consensus." Journal of Environmental Planning and Management no. 47 (1):3-17.

Conrad, E., Cassar, L. Christie, M. and Fazey, I . 2011. "Hearing but not listening? A participatory assessment of public participation in planning." Environment and Planning C: Government and Policy no. 29:761-782.

CSIRO. 2007. Climate Change in Australia. Technical Report 2007 (online), Available:

www.climatechangeinaustralia.gov.au/technical_report.php 2010).

(20 May

Department of Climate Change. 2009. Climate Change Risks to Australia's Coast. A first pass national assessment: Commonwealth Government of Australia.

Department of Planning and Community Development. 2007. Wellington Planning Scheme. edited by The State of Victoria.

Department of Premier and Cabinet. 2011. Tasmanian Coastal Adaptation Decision Pathways Project. The State of Tasmania.

Environmental Planning and Assessment Regulation 2000 (NSW)

Eshuis, J., and C. Van Woerkum. 2003. "Trust and monitoring in governance processes: lessons from landscape management by farmers in a Dutch municipality." Journal of Environmental Policy \& Planning no. 5 (4):379396.

ETHOS NRM Pty Ltd and Water Technology. 2008. Climate Change And Sea Level Rise Implications: Ninety Mile Beach and Lake Reeve Honeysuckles to Paradise Beach. Final Report, prepared for the Wellington Shire Council.

Few, R., K. Brown, and E. Tompkins. 2007. "Public participation and climate change adaptation: avoiding the illusion of inclusion." Climate Policy no. 7:46-59.

Fischer, F. 2006. "Participatory governance as deliberative empowerment. The cultural politics of discursive space." American Review of Public Administration no. 36 (1):19-40.

Giddens, A. 1998. The third way. The renewal of social democracy. Cambridge: Polity Press.

Golden Beach Property Rights Action Group. Fighting for Property Rights on Golden Beach "INAPPROPRIATE SUBDIVISION" under the Victorian 
Coastal Strategy. 2008 [cited June 8 Available from http://90mile.blogspot.com/

Gosford City Council. 2010. Sea level rise fact sheet.

Gosford City Council. undated. Community Engagement Summary Report for the Community Strategic Plan.

Gurran, N., B. Norman, C. Gilbert, and E. Hamin. 2011. Planning for climate change adaptation in Coastal Australia: State of practice. Sydney: Report No. 4 for the National Sea Change Taskforce, Faculty of Architecture, Design and Planning, University of Sydney.

Harman, B. P., S. Heyenga, B. M. Taylor, and C. S. Fletcher. 2013. "Global Lessons for Adapting Coastal Communities to Protect against Storm Surge Inundation." Journal of Coastal Research. doi: 10.2112/jcoastres-d13-00095.1.

Hartz-Karp, J. 2004. "Harmonising divergent voices: sharing the challenge of decision-making." Public Administration Today no. 2:14-19.

Head, B. W. 2011. "Australian experience: Civic engagement as symbol and substance." Public Administration and Development no. 31 (2):102-112. doi: $10.1002 /$ pad.599.

Head, B. W. . 2007. "Community Engagement: Participation on Whose Terms?" Australian Journal of Political Science no. 42 (3):441 - 454.

Healey, P. 1992. " The Communicative Turn in Planning Theory." Town Planning Review no. 63 (2):143-162. 2006. Collaborative Planning. Changing Places in fragmented Societies. Hampshire: Palgrave MacMillan.

Hennessy, K., B. Fitzharris, B. C. Bates, N. Harvey, M. Howden, L. Hughes, J. Salinger, and R.Warrick. 2007. "Australia and New Zealand." In Climate Change 2007: Impacts, Adaptation and Vulnerability. Contribution of Working Group II to the Fourth Assessment Report of the Intergovernmental Panel on Climate Change, edited by M.L. Parry, O.F. Canziani, J.P. Palutikof, P.J. van der Linden and C.E. Hanson, 507-540. Cambridge: Cambridge University Press.

Hindmarsh, R., and C. Matthews. 2008. "Deliberative Speak at the Turbine Face: Community Engagement, Wind Farms, and Renewable Energy Transitions, in Australia." Journal of Environmental Policy \& Planning no. $10(3): 217-232$.

Hobson, K., and S. Niemeyer. 2011. "Public responses to climate change: The role of deliberation in building capacity for adaptive action." Global Environmental Change no. 21 (3):957-971. doi: http://dx.doi.org/10.1016/j.gloenvcha.2011.05.001.

Hopkins, M. 2008. "Climate change impact and response in Western Australia." Australian Planner no. 45 (4):12-17.

International Association for Public Participation (IAP2). IAP2 Public Participation Spectrum 2007 [cited May 30 2011. Available from http://www.iap2.org/ associations/4748/files/IAP2\%20 Spectrum_vertical.pdf

Jamieson, D. 2006. "An American paradox." Climatic Change no. 77:97-102. 
Keen, M., D. Mercer, and J. Woodfull. 1994. "Approaches to environmental management at the Australian local government level: Initiatives and limitations." Environmental Politics no. 3 (1):43-67.

Kloprogge, P., and J. Van Der Sluijs. 2006. "The Inclusion of Stakeholder Knowledge and Perspectives in Integrated Assessment of Climate Change." Climatic Change no. 75 (3):359-389. doi: 10.1007/s10584-0060362-2.

Lahiri-Dutt, K. 2004. "'I plan, you participate': A southern view of community participation in urban Australia." Community Development Journal no. 39:13-27.

Land Use Planning and Approvals Act 1993 (TAS)

Leitch, A., B. Harman, and M. Lane. 2010. "From blueprint to footprint: climate change and the challenge for planning." In Adaptation to climate change. Law and policy, edited by T. Bonyhady, A. Macintosh and J. McDonald, 63-79. Sydney: The Federation Press.

Local Government Act 1989 (VIC)

Lorenzoni, I., S. Nicholson-Cole, and L. Whitmarsh. 2007. "Barriers perceived to engaging with climate change among the UK public and their policy implications." Global Environmental Change no. 17:445-459.

Low Choy, D., S. Serrao-Neumann, F. Crick, G. Schuch, M. Sanò, R. van Staden, O. Sahin, B. Harman, and S. Baum. 2012. Adaptation Options for Human Settlements in South East Queensland - Main Report, published report for the South East Queensland Climate Adaptation Research Initiative: Griffith University.

Manwaring, R. 2010. "Unequal voices: 'strategic' consultation in South Australia." Australian Journal of Public Administration no. 69 (2):178-189.

McDonald, J. 2010. "Paying the price of adaptation: compensation for climate change impacts." In Adaptation to climate change. Law and policy, edited by T. Bonyhady, A. MaCintosh and J. McDonald, 234-264. Sydney: The Federation Press.

McDonald, J., S. Baum, F. Crick, J. Czarnecki, G. Field, D. Low Choy, J. Mustelin, M. Sanò, and S. Serrao-Neumann. 2010. Climate change adaptation in South East Queensland human settlements: Issues and context, report for the South East Queensland Climate Adaptation Research Initiative, Griffith University.

McGuirk, P. M. 2001. "Situating communicative planning theory: context, power, and knowledge." Environment and Planning A no. 33 (2):195-217.

Measham, T., B. Preston, T. Smith, C. Brooke, R. Gorddard, G. Withycombe, and C. Morrison. 2011. "Adapting to climate change through local municipal planning: barriers and challenges." Mitigation and Adaptation Strategies for Global Change no. 16: 889-909.

Meinhardt Infrastructure \& Environment Pty Ltd. 2007. The Honeysuckles Urban Design Framework. In Coastal Towns Design Framework Volume 3. Wellington Shire Council. 
Mercer, D., and B. Jotkowitz. 2000. "Local Agenda 21 and Barriers to Sustainability at the Local Government Level in Victoria, Australia." Australian Geographer no. 31 (2):163-181.

Milly, P., J. Betancourt, M. Falkenmark, R. Hirsch, Z. Kundzewicz, D. Lettenmaier, and R. Stouffer. 2008. "Stationarity Is Dead: Whither Water Management?" Science no. 319:573-574.

Moser, S. 2009. "Making a difference on the ground: the challenge of demonstrating the effectiveness of decision support." Climatic Change no. 95 (1):11-21. doi: 10.1007/s10584-008-9539-1.

National Climate Change Adaptation Research Facility (NCCARF), Department of Climate Change and Energy Efficiency (DCCEE), and Australian National University, . 2012. Informing Adaptation Policy- NCCARF and ANU Workshop 3-4 May 2012, Report for Policy Makers. Department of Climate Change and Energy Efficiency, National Climate Change Adaptation Research Facility and the Australian National University, Australia.

Norman, B. 2010. A low carbon and resilient urban future. An integrated approach to planning for climate change. Commonwealth of Australia, Department of Climate Change and Energy Efficiency

NSW Sea Level Rise Policy Statement 2009 (NSW)

Olsson, A. 2009. "Relational rewards and communicative planning: Understanding actor motivation." Planning Theory (8):263-281.

Osborne, K., C. Bacchi, and C. Mackenzie. 2008. "Gender Analysis and Community Consultation: The Role of Women's Policy Units." Australian Journal of Public Administration no. 67 (2):149-160. doi: 10.1111/j.14678500.2008.00578.x.

Planning and Environment Act 1987 (VIC)

Poortinga, W., A. Spence, L. Whitmarsh, S. Capstick, and N.F. Pidgeon. 2011. "Uncertain climate: An investigation into public scepticism about anthropogenic climate change." Global Environmental Change no. 21 (3):1015-1024. doi: http://dx.doi.org/10.1016/j.gloenvcha.2011.03.001.

Quay, R. 2010. "Anticipatory Governance." Journal of the American Planning Association no. 76 (4):496-511. doi: Pii 926306037

Quick, K., and M. Feldman. 2011. "Distinguishing Participation and Inclusion." Journal of Planning Education and Research no. 31:272-290.

Renn, O. 2006. "Participatory processes for designing environmental policies." Land Use Policy no. 23 (1):34-43. doi: http://dx.doi.org/10.1016/j.landusepol.2004.08.005.

Serrao-Neumann, S., F. Crick, B. Harman, M. Sano, O. Sahin, R. Van Staden, G. Schuch, S. Baum, and D. Low Cho. 2014. "Improving cross-sectoral climate change adaptation for coastal settlements: insights from South East Queensland, Australia." Regional Environmental Change no. 14 (2): 489-500.

Serrao-Neumann, S., B. P. Harman, and D. Low Choy. 2013. "The Role of Anticipatory Governance in Local Climate Adaptation: Observations from Australia." Planning Practice \& Research no. 28: 440-463. 
SGS Economics and Planning. 2012. Tasmanian Coastal Adaptation Pathways Project Lauderdale Scenario Planning Summary.

State Government of Victoria. undated. Future Coasts Program (online),

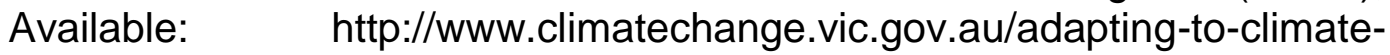
change/future-coasts

Steele, W. 2009. "Australian Urban Planners: Hybrid Roles and Professional Dilemmas?" Urban Policy and Research no. 27 (2):189-203. doi: 10.1080/08111140902908873.

Sutton, S G., and R C. Tobin. 2011. "Constraints on community engagement with Great Barrier Reef climate change reduction and mitigation." Global Environmental Change no. $21 \quad$ (3):894-905. doi: http://dx.doi.org/10.1016/j.gloenvcha.2011.05.006.

Taylor, B M., B P. Harman, and M Inman. 2013. "Scaling-Up, Scaling-Down, and Scaling-Out: Local Planning Strategies for Sea-Level Rise in New South Wales, Australia." Geographical Research no. 51 (3):292-303. doi: 10.1111/1745-5871.12011.

The Mercury. 2012. "One storm from disaster." The Mercury, May 20.

Toth, F. L, and E. Hizsnyik. 2008. "Managing the inconceivable: participatory assessments of impacts and responses to extreme climate change." Climatic Change no. 91 (1-2):81-101. doi: 10.1007/s10584-008-9425-x.

Videira, N., P. Antunes, R. Santos, and G. Lobo. 2006. "Public and Stakeholder Participation in European Water Policy: a Critical Review of Project Evaluation Processes." European Environment no. 16:19-31.

Water Research Laboratory (WRL). 2011. Inspection of Clarence City Beaches following winter 2011 Storm Events. University of New South Wales.

Wellington Shire Council. 2007. Wellington Coast Subdivision Strategy. The Honeysuckles to Paradise Beach. Wellington Shire Council.

. 2011. Draft Community Engagement Strategy 2011-15. Wellington Shire Council.

- 2012. Ninety Mile Beach Plan. Wellington Shire Council.

—. undated. Wellington Planning Scheme Amendment C71 Explanatory Report.

Wimbush, N., J. Holdsworth, and R. Gowans. 2009. Wellington Planning Scheme amendment C50 Coastal Towns Urban Design Frameworks.

Wiseman, J., L. Williamson, and J. Fritze. 2010. "Community engagement and climate change: learning from recent Australian experience." International Journal of Climate Change Strategies and Management no. 2 (2):134-147.

Yetano, A., S. Royo, and B. Acerete. 2010. "What is driving the increasing presence of citizen participation initiatives?" Environment and Planning C: Government and Policy no. 28:783-802. 


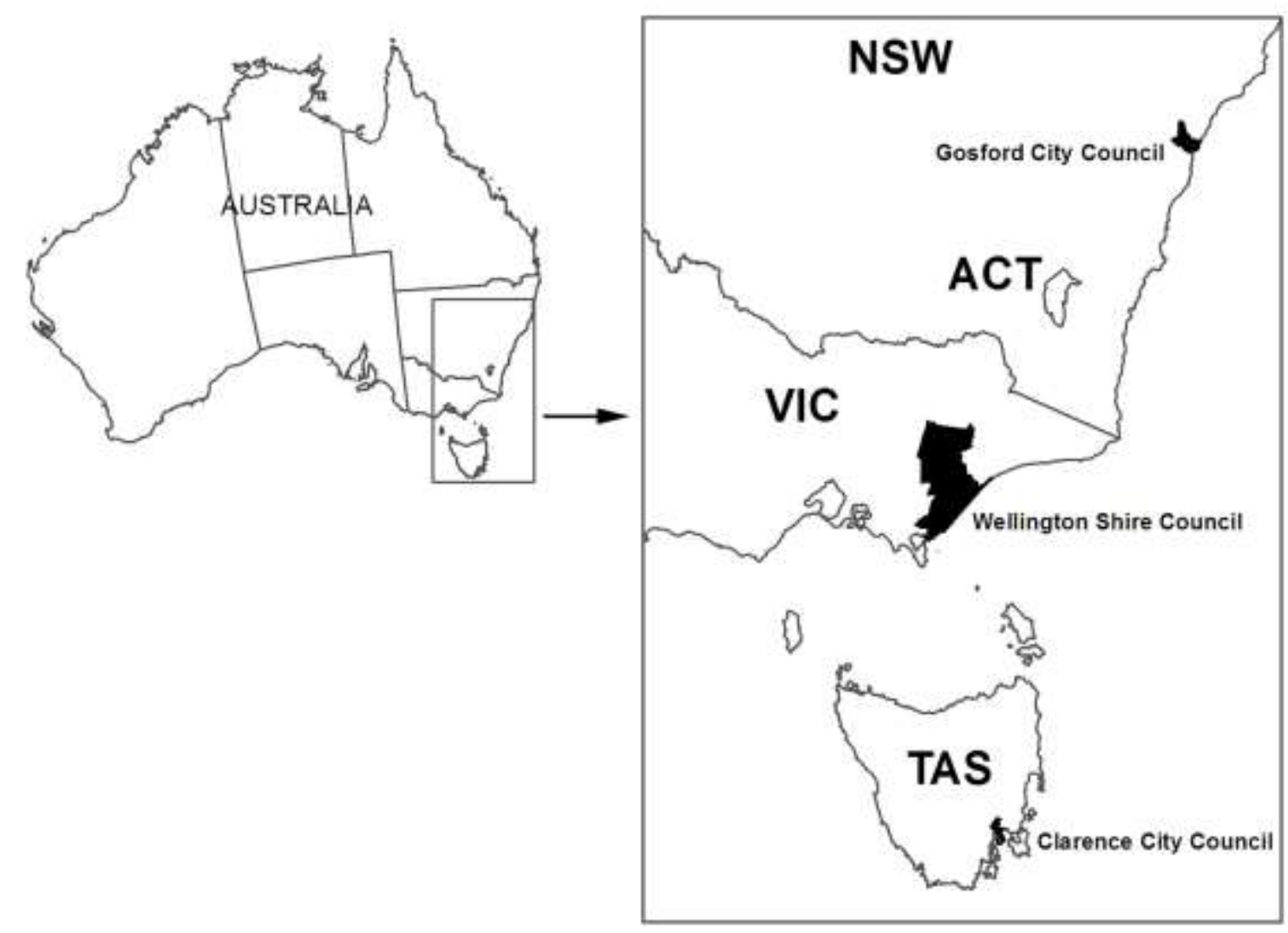

\section{Gosford City Council}

Gosford City Council is located 77 kilometres north of Sydney, New South Wales (NSW), with an area of approximately $1,000 \mathrm{~km}^{2}$ and a population of over 16,000 people. Gosford's coastal zone includes approximately 140 kilometres of foreshore area, including Brisbane Water and Hawkesbury River, four major coastal lagoons and 14 kilometres of beaches.

\section{Wellington Shire Council}

Wellington Shire Council is located in Central Gippsland at approximately 200 kilometres east of Melbourne, Victoria (VIC). With a current population of approximately 43,000 inhabitants and spaning an area of $10,809 \mathrm{~km}^{2}$, the Shire has relatively unspoiled coastal and lake areas.

\section{Clarence City Council}

Clarence City is located to the east of Hobart, Tasmania (TAS). The Clarence City Council covers an area of $386 \mathrm{~km}^{2}$ and has a population of approximately 47,461 inhabitants. The Council manages $191 \mathrm{~km}$ of coastline.

Figure 1. Case studies 


\begin{tabular}{|c|c|c|c|c|}
\hline Information & Consultation & Involvement & Collaboration & Empowerment \\
\hline $\begin{array}{l}\text { 'Balanced and } \\
\text { objective information } \\
\text { is provided to assist the } \\
\text { public in understanding } \\
\text { the problem, } \\
\text { alternatives, } \\
\text { opportunities and/or } \\
\text { solutions'. }\end{array}$ & $\begin{array}{l}\text { Public feedback is } \\
\text { sought 'on analysis, } \\
\text { alternatives and/or } \\
\text { decisions' related to } \\
\text { issues in question. }\end{array}$ & $\begin{array}{l}\text { the public is directly } \\
\text { involved to ensure } \\
\text { their 'concerns and } \\
\text { aspirations are } \\
\text { consistently } \\
\text { understood and } \\
\text { considered' } \\
\text { throughout the } \\
\text { process. }\end{array}$ & $\begin{array}{l}\text { Partnerships with the } \\
\text { public are established } \\
\text { to develop } \\
\text { 'alternatives and } \\
\text { identify preferred } \\
\text { solutions' in the } \\
\text { decisions. }\end{array}$ & $\begin{array}{l}\text { Decisions to are to be } \\
\text { undertaken by the } \\
\text { public. }\end{array}$ \\
\hline $\begin{array}{l}\text { Techniques } \\
\text { Information sheets, } \\
\text { public exhibits and } \\
\text { websites }\end{array}$ & $\begin{array}{l}\text { Techniques } \\
\text { Public comments, } \\
\text { surveys and } \\
\text { meetings }\end{array}$ & $\begin{array}{l}\text { Techniques } \\
\text { Workshops and other } \\
\text { participation formats } \\
\text { that include } \\
\text { deliberation }\end{array}$ & $\begin{array}{l}\text { Techniques } \\
\text { Public committees } \\
\text { and participatory } \\
\text { decision-making }\end{array}$ & $\begin{array}{l}\text { Techniques } \\
\text { Delegate decisions } \\
\text { and ballots }\end{array}$ \\
\hline \multicolumn{3}{|c|}{ Weaker participation form } & \multicolumn{2}{|c|}{ Stronger participation form } \\
\hline
\end{tabular}

Figure 2. Progressive scale of public participation based on the IAP2 framework 
Table 1. Selected planning processes across case study areas

\begin{tabular}{|c|c|c|c|}
\hline \multirow{2}{*}{$\begin{array}{l}\text { Local } \\
\text { Government } \\
\text { Area }\end{array}$} & \multicolumn{3}{|c|}{ Planning Processes } \\
\hline & $\begin{array}{l}\text { Strategy, Plan, Project, } \\
\text { Initiative }\end{array}$ & Key Aims & Targeted Issues \\
\hline \multirow[t]{2}{*}{$\begin{array}{l}\text { Gosford City } \\
\text { Council (NSW) }\end{array}$} & $\begin{array}{l}\text { DCP125 - Coastal } \\
\text { Frontage (statutory } \\
\text { development control } \\
\text { plan) }\end{array}$ & $\begin{array}{l}\text { Production of a series of hazard maps and } \\
\text { outlined development standards in coastal } \\
\text { areas }\end{array}$ & $\begin{array}{l}\text { Compliance to NSW } \\
\text { sea level rise planning } \\
\text { benchmarks (Gosford } \\
\text { City Council 2010) }\end{array}$ \\
\hline & $\begin{array}{l}\text { Notification on planning } \\
\text { certificates S149(5) }\end{array}$ & $\begin{array}{l}\text { To advise to property owners of the risk of a } \\
\text { sea level rise of up to } 90 \mathrm{~cm} \text { by } 2100\end{array}$ & \\
\hline \multirow[t]{2}{*}{$\begin{array}{l}\text { Wellington Shire } \\
\text { Council (VIC) }\end{array}$} & $\begin{array}{l}\text { Wellington Coast } \\
\text { Subdivision Strategy } \\
\text { (Wellington Shire } \\
\text { Council 2007) }\end{array}$ & $\begin{array}{l}\text { (i) To establish a settlement structure for the } \\
\text { coast; (ii) to ensure that developments were } \\
\text { aligned with environmental values strategy; } \\
\text { (iii) to encourage developments to provide } \\
\text { maximum community and economic benefits; } \\
\text { (iv) to improve infrastructure provision in the } \\
\text { area; (v) to take into consideration landowner } \\
\text { concerns and share financial costs related to } \\
\text { establishing a new settlement structure for the } \\
\text { area; and (vi) to reduce ongoing uncertainty } \\
\text { for the future of the area to landowners, local } \\
\text { authority and other interested parties through } \\
\text { the establishment of a planning and } \\
\text { management framework }\end{array}$ & $\begin{array}{lr}\text { Housing } & \text { estates } \\
\text { inappropriately } & \\
\text { developed in the } & 1950 \text { s } \\
\text { and 1960s } & \text { along } \\
\text { Ninety Mile } & \text { Beach } \\
\text { area; } & \text { high } \\
\text { environmental } & \text { values } \\
\text { (Wellington } & \text { Shire } \\
\text { Council 2007) } & \end{array}$ \\
\hline & $\begin{array}{l}\text { Urban Design } \\
\text { Framework (Meinhardt } \\
\text { Infrastructure \& } \\
\text { Environment Pty Ltd } \\
\text { 2007) }\end{array}$ & $\begin{array}{l}\text { To guide future developments in the area in } \\
\text { terms of their 'location, type and extent' }\end{array}$ & \\
\hline \multirow[t]{2}{*}{$\begin{array}{l}\text { Clarence City } \\
\text { Council (TAS) }\end{array}$} & $\begin{array}{l}\text { Climate Change Impacts } \\
\text { on Clarence Coastal } \\
\text { Areas (Clarence City } \\
\text { Council 2009) }\end{array}$ & $\begin{array}{l}\text { To assess the risk, risk perception and } \\
\text { vulnerability of the city to climate change }\end{array}$ & $\begin{array}{l}\text { Residential dwellings } \\
\text { at risk of coastal } \\
\text { erosion and inundation } \\
\text { issues to increase due } \\
\text { to future sea level rise } \\
\text { and storm activity } \\
\text { (Aquenal Pty Ltd } \\
2010 a \text {, } 2010 b ; \\
\text { Clarence City Council } \\
2012 \text { ) }\end{array}$ \\
\hline & $\begin{array}{l}\text { Tasmanian Coastal } \\
\text { Adaptation Decision } \\
\text { Pathways (TCAP) }\end{array}$ & $\begin{array}{l}\text { To develop long term responses to climate } \\
\text { change in the Lauderdale area }\end{array}$ & $\begin{array}{l}\text { Widespread beach } \\
\text { erosion and flooding } \\
\text { along Roches Beach } \\
\text { caused by significant } \\
\text { storm event in July } \\
2011\end{array}$ \\
\hline
\end{tabular}


Table 2. Comparing the three case studies regarding IAP2 public participation framework.

Gosford City Council (NSW)
Wellington Shire Council (VIC)
Clarence City Council (TAS)

Information: To provide the public with balanced and objective information to assist them in understanding the problem, alternatives, opportunities and/or solutions.

- Public display of sea level rise (SLR) maps

- Fact sheets and web pages with general information on SLR and Council's response

- SLR-relevant notation on planning certificates Section 149(5)

- Community consultation fora - advertised through local media and website
- Newsletters on the Urban Design Framework - UDF project.

- Public display of draft UDF report.

- Draft UDF made available for comments.

- Newsletters, website, direct mail and press releases.

- Public display of planning scheme amendment to implement UDF.

Consultation: To obtain public feedback on analysis, alternatives and/or decisions

- Public submissions on maps considered

- New information disseminated to community at Council meetings

- Feedback on SLR maps considered at Council meeting
- Public meeting to identify community values and key issues

- Community feedback on draft report

- Community to provide comment on Draft UDF

- Planning scheme amendments to implement UDF included hearings by independent pane

- Community feedback considered

- Public submissions to UDF
- Comprehensive communication plan

- Press conference - background to project and report findings

- Two public meetings / fora announced mail out to all residents

Involvement: To work directly with the public throughout the process to ensure that public concerns and aspirations are consistently understood and considered

- Council participated in fora organised by community groups
- Detailed findings of the report / project and proposed policy options up for public discussion

- Community contributed to select preferred adaptation pathway

Collaboration: To partner with the public in each aspect of the decision, including the development of alternatives and the identification of the preferred solution
- Management committees and task groups involved community members.
- Community advisory groups and networks contributed to UDF development.
- None identified
- None - although Council states this occurs through Council elections
- Community groups take responsibility on specific Council project/issue 